\title{
The Fate of the Formal Method in Slovak Literary Studies
}

\author{
Róbert Gáfrik (Bratislava)
}

\begin{abstract}
This paper maps the reception of Russian formalism in Slovak literary studies in the 20th century. It discusses the historical and cultural context of the 1930s when Slovak literary scholars came into contact with the formal method. The interest of Slovak scholars in formalism was connected with their efforts to explore the foundations of structuralism and to contribute to the development of the new structuralist theory. The political situation in the country in the 1940s and the 1950s was not favourable to the formalist/structuralist approach to literature. Slovak literary studies suffered under ideological constraints. Formalism was officially repudiated by the wartime Slovak State as well as the subsequent communist regime. In the 1960s, Slovak structuralism started to flourish anew and interest in formalism was briefly revived until it was once more suppressed by the political establishment. Structuralism was rehabilitated after the Velvet Revolution of 1989. Nevertheless, at that time, the structuralist initiative had already lost the momentum to stimulate the development of literary theory.
\end{abstract}

\section{Key words}

Russian formalism; structuralism; history of Slovak literary studies; Marxism; Mikuláš Bakoš; Jan Mukařovský; Roman Jakobson; Dionýz Ďurišin

\begin{abstract}
Abstrakt
Príspevok mapuje recepciu ruského formalizmu v slovenskej literárnej vede 20. storočia. Rozoberá historický a kultúrny kontext 30. rokov, ked' slovenskí literárni vedci prišli do styku s formálnou metódou. Záujem slovenských vedcov o formalizmus súvisel s ich úsilím preskúmat' základy štrukturalizmu a prispiet’ k rozvoju novej štrukturalistickej teórie. Politická situácia v krajine nebola v 40. a 50. rokoch priaznivá pre formalistický/štrukturalistický prístup k literatúre. Slovenská literárna veda trpela ideologickými obmedzeniami. Formalizmus bol oficiálne zapudený vojnovým Slovenským štátom, ako aj následným komunistickým režimom. V 60. rokoch začal slovenský štrukturalizmus znova prekvitat' a záujem o formalizmus sa krátko na to oživil, až kým ho opät' nepotlačil politický establishment. Po Nežnej revolúcii v roku 1989 bol štrukturalizmus rehabilitovaný. V tom čase však už štrukturalistický prístup stratil hybnú silu stimulovat' rozvoj literárnej teórie.
\end{abstract}

\section{Klúčové slová}

ruský formalizmus; štrukturalizmus; dejiny slovenskej literárnej vedy; marxizmus; Mikuláš Bakoš; Jan Mukařovksý; Roman Jakobson; Dionýz Ďurišin 


\section{Slovak Literary Studies in the 1930s and the Reasons for the Reception of Russian Formalism ${ }^{1}$}

After the end of the First World War in 1918 and with the resulting breakup of Austria-Hungary, the Slovaks became one of the nations forming Czechoslovakia. Life in democratic Czechoslovakia represented the fulfilment of the wishes of the Slovaks for their free national development. With the strong support of Czech intellectuals, the Slovaks also started building their own academic institutions. In 1919, Comenius University was established in Bratislava, and Matica slovenská, the main national cultural institution that had played an important role in the struggle for national independence, resumed its activities after 44 years during which the Slovaks had fought forced Magyarization. Both institutions contributed to the development of Slovak literary studies, which drew on the tradition of national literary criticism represented by Svetozár Hurban-Vajanský (1847-1916), Jozef Škultéty (1853-1948) and Jaroslav Vlček (1860-1930).

In the 1930s, some scholars started to perceive as insufficient the lingering romanticism of the previous generation of literary scholars as well as the positivist literary historicism that had found a foothold at Comenius University and was particularly represented by the Czech scholar Albert Pražák (1880-1956). An important change in literary studies in Slovakia was brought about by Jan Mukařovský, who, commuting every week from Prague, taught in Bratislava from 1931 to 1937 and introduced Slovak literary scholars to structuralism. ${ }^{2}$ The Slovak art scholar Ján Bakoš described Slovak structuralism as a "symbolic jump", "an attempt to overcome the backwardness compared with Western rationalism by the power of an intellectual model, to overcome the distance between the agrarian-feudal and the industrial culture by the power of ideas". ${ }^{3}$ Slovak structuralism represented a fundamental initiative, and all the important Slovak literary scholars of the $20^{\text {th }}$ century came into contact with it.

An all-around transformation in scientific and artistic activities was underway in Slovakia in the 1930s. At the Faculty of Arts of Comenius University in Bratislava, a group of young graduates became interested in new theoretical and methodological developments in European science, especially in literary studies, linguistics, philosophy, and ethnology. In 1937, they formed the Association for Scientific Synthesis (Spolok pre vedeckú syntézu). Over the next three years, until its dissolution in 1940, the members of the association organized more than 40 lectures and published a large amount of work. As the name of the association suggests, its members were interested in scientific synthesis, i.e. the creation of a model of science applicable to various disciplines. How-

1 The first version of this paper was presented at the conference on Russian Formalism \& Eastern and Central European Literary Theory held in Sheffield, UK, in 2015 and it appeared in Slovak as GÁFRIK, Róbert: Mikuláš Bakoš a osud ruského formalizmu na Slovensku. In: Mikuláš Bakoš a moderná literárna veda. Ed. Dušan Teplan. Nitra: Univerzita Konštantína Filozofa v Nitre, 2016, pp. 85-95.

2 TOMČÍK, Miloš: Bratislavské roky Jana Mukařovského. Slovenská literatúra, Vol. 38, 1991, No. 5-6, pp. 346-357.

3 BAKOŠ, Ján: Štrukturalizmus na Slovensku ako symbolický skok. In: Československý štrukturalizmus a viedenský scientizmus. Eds. Ján Bakoš - Peter Michalovič. Bratislava: Stimul, 1992, p. 11. All translations from Slovak are mine. 
ever, they were mostly concerned with the social sciences and humanities because the natural sciences were not yet very developed at that time in Slovakia. Igor Hrušovský (1907-1978), who is best known for his book Téoria vedy ("Theory of Science", 1941), found support for the idea of scientific synthesis in the philosophy of the Vienna circle which pursued the idea of unified science (Einheitswissenschaft). The members of the Association for Scientific Synthesis chose structuralism as the metalanguage for the different scientific disciplines. This new scientific approach was uncompromising towards other approaches. It disapproved of all research that was not based on a logical methodology. It is commonly defined as scientism.

Such was the context in which Russian formalism entered Slovak literary studies. It was a result of the efforts of Mikuláš Bakoš (1914-1972), ${ }^{4}$ a student of Jan Mukařovský and one of the leading figures of the Association for Scientific Synthesis, that the first translations of the works of the Russian formalists started appearing in 1936 in periodicals such as Slovenské smery umelecké a kritické ("Slovak Movements in Art and Criticism”), Slovenské pohl'ady ("Slovak Views") and Politika ("Politics") - 32 articles altogether. Slovak readers could thus read the fundamental works of Osip Brik, Boris Eikhenbaum, Pyotr Bogatyrev, Boris Engelhardt, Roman Jakobson, Viktor Shklovsky, and Yury Tynyanov. Mikuláš Bakoš worked in close collaboration with Roman Jakobson, who at that time resided in nearby Brno and occasionally gave lectures at the university in Bratislava, where he found an interested audience. ${ }^{5}$ Bakoš jokingly wrote to the literary critic Andrej Mráz (1904-1964) about one of his journeys back from Brno: "I am carrying away with me a briefcase full of formalists who are to take Slovak scholarship into the 'one-sidedness' of 'formalism'." 6

The Slovak structuralist and translation theorist Anton Popovič (1933-1984) saw basically two reasons for the favourable reception of formalism in this period. The first reason was the effort to establish Slovak science and scholarship. Slovak scholars strove for scholarly independence from the Czechs, for the ability to have their own perspective and to develop new ideas. For this reason, they did not mechanically accept even such an advanced theoretical system as Czech structuralism and instead attempted to perform an in-depth examination of the Russian formalism upon which it had drawn. ${ }^{7}$ Mikulás Bakoš contemplated publishing a volume of formalist studies. He wrote to Andrej Mráz in 1937: "When I decided to publish this volume, I pursued only one goal - to contribute to Slovak culture with a translation of theoretical works of an epochal significance which will determine the further development of literary studies, and to do it before the Czechs in order to show that the

4 For detailed information on Bakoš's life as well as his full publication list and other documents related to his works see TEPLAN, Dušan (ed.): Mikuláš Bakoš a moderná literárna veda. Nitra: Univerzita Konštantína Filozofa v Nitre, 2016.

5 PIŠÚT, Milan: Formalizmus a štrukturalizmus. Slovenské smery umelecké a kritické, Vol.1, 1933-1934, No. 1, p. 265.

6 Quoted in POPOVIČ, Anton: Štrukturalizmus v slovenskej vede 1931-1949. Martin: Matica slovenská, 1970 , p. 23.

7 Ibidem, p. 25. 
Slovaks are detaching themselves from them and do not imitate them in everything, that they now orient themselves."

The second reason Popovič saw for the favourable reception of formalism in Slovakia was the parallel situation in Russia. Russian formalism was closely associated with Russian symbolism and futurism. In Slovakia, it was nadrealizmus that played a comparable role in the development of literary studies. Nadrealizmus is the literal translation of the French word surrealisme, although it does not have absolutely the same meaning. It is a modification of classical surrealism. Nadrealizmus tried to demonstrate that the rationality of science and the irrationality of art are two sides of the same phenomenon, "an expression of the gradual differentiation of mental functions". ${ }^{9}$

\section{Mikuláš Bakoš as the Mediator of Russian Formalism in Slovakia}

The interest of Slovak literary scholars in formalism in the 1930s was motivated by the effort to provide a scientific basis for literary studies. Literary critics, including Mikuláš Bakoš himself as well as Michal Považan (1913-1952) and Klement Šimončič (1912-2010), applied formalist theoretical postulates in their book reviews, which represented the first steps towards introducing formalism into Slovak scholarship. ${ }^{10}$

Mikuláš Bakoš was the most prominent exponent of formalism in Slovakia. Other literary scholars (such as Andrej Mráz and Milan Pišút) had a rather eclectic attitude to new literary theories. Bakoš published two books that represent the culmination of the Slovak interest in formalism: an anthology of formalist works which appeared in 1942 (with 1941 as the year of printing) under the title Teória literatúry. Výbor z „formálnej metódy " "Theory of Literature. A Selection from the 'Formal Method") and his own study of Slovak poetry titled Vývin slovenského verša ("Development of Slovak Verse", 1939).

The anthology of formalist works was already prepared for publication in 1937. Bakoš started working on it under the supervision of Roman Jakobson, who originally was to write the introduction that, in the end, he did not write because he had to leave the country. The anthology could appear only four years later. The reason was that Bakoš was not able to find a publisher. He eventually succeeded in financing the publication through subscriptions. Already during the negotiations with various publishers, Bakoš realized that he would not be able to include all the texts he had intended in the anthology. The printed version contained only two-thirds of the prepared material.

The anthology is a collection of fundamental, programmatic and representative studies by Boris Eikhenbaum, Viktor Shklovsky, Roman Jakobson, Viktor Zhirmunsky, Pyotr Bogatyrev, Yury Tynyanov, Boris Tomashevsky, Osip Brik, Lev Yakubinsky, and Viktor

8 Qtd. ibidem.

9 BAKOŠ, Mikuláš: Áno a nie. In: Avantgarda 38. Ed. Mikuláš Bakoš. Bratislava: Slovenský spisovatel, 1969, p. $181-182$.

10 POPOVIČ, Anton: Formálna metóda v slovenskej literárnej vede. Slovenské pohlady, Vol. 81, 1965, No. 12, pp. 81-90. 
Vinogradov. ${ }^{11}$ It places emphasis on studies that corresponded with the scientistic aspirations of the Slovak literary studies of the day. The first half of the book is devoted to the problems of poetics; the other half to the problems of poetry and prose. The anthology was appreciated for the choice of texts as well as for the high quality of the translation work and Bakoš's annotations, in which he not only explained but also confronted the ideas of the formalists with Slovak literary material. The translations are appended by a detailed bibliography of the works of the formalists and of related studies. Bakoš was guided by a specific goal: He perceived the need for a revision of the assumptions on which Slovak literary historical research was based. After Jaroslav Vlček's ground-breaking work on the history of Slovak literature (Dejiny literatúry slovenskej, 1890), Bakoš did not see anything of comparable importance and believed that formalism would provide the tools for a revival of literary studies. He said in the introduction that "the theoretical apparatus has been worn down". ${ }^{12}$ With the anthology, he therefore sought to revive Slovak theoretical thinking about literature and encourage " a sense for the concrete phenomena of the artistic structure of a literary work". ${ }^{13}$

The anthology resonated especially with university students and young high school teachers. Even intellectuals unsympathetic to the activities of the Association for Scientific Synthesis were interested in it. ${ }^{14}$ The translation of the texts of the Russian formalists provided a foundation for the further development of Slovak literary theoretical terminology. Popovič identified three such clusters of terminology: 1. terminology borrowed from traditional poetics (acrostic, allegory, elegy, etc.); 2. old terminology reconceptualized by the formalists (poetic character; fabula, syuzhet, monologue, dialogue, composition, etc.); 3. new terminology coined by the theorists as tools for a new type of analysis (literary process, literary line, actualization, metre algebraization, autonomy, aesthetic function, text equivalent, etc.). ${ }^{15}$ This terminology was adopted by Slovak literary scholars and remained in use well beyond the 1930s and the 1940s. It was also accepted in later literary studies, although it was no longer strictly tied to the formal method. Numerous publications testify to the popularity of these concepts in Slovak literary scholarship at least until the 1990s.

Bakoš's book on Slovak poetry, Vývin slovenského verša ("Development of Slovak Verse", 1939) was the most important result of his theoretical studies. It was the first monograph on Slovak historical poetics which applied a consistent theoretical system. Bakoš drew on theories of poetic rhythm as they were elaborated by the formalists. He explored the

11 For an analysis of Bakoš’s translations see PAŠTEKOVÁ, Soňa: Niekol'ko poznámok k Bakošovým prekladom prác ruských formalistov (B. Ejchenbaum: Ako je napisaný Gogol’ov Plášt?). In: Preklad a tlmočenie XII. Hybridita a kreolizácia v preklade a translatológii. Eds. Anita Hutková - Martin Dvojčoš. Banská Bystrica: Belanium, 2016, pp. 85-94; PAŠTEKOVÁ, Soňa: Koncepcie ruského formalizmu a Mikuláš Bakoš (literárnovedná reflexia v peripetiách doby). In: Dialog kultur IX. Sborník příspěvků z mezinárodní vědecké konference Hradec Králové 17. - 18. ledna 2017. Ed. Jaroslav Sommer. Hradec Králové: Gaudeamus, 2018, pp. 25-39. BAKOŠ, Mikuláš: Úvod. In: Teória literatúry. Výbor z „formálnej metódy“. Trnava: Fr. Urbánek a spol., 1941, p. 10.

13 Ibidem, p. 11.

14 POPOVIČ, Anton: Formálna metóda v slovenskej literárnej vede. Op. cit., p. 86.

15 Ibidem, p. 89. 
linguistic foundations of Slovak versification and analysed the rhythmic structures in the Slovak poetry of the $19^{\text {th }}$ and $20^{\text {th }}$ centuries. However, some scholars maintain that the work is not strictly formalist but stands somewhere between formalism and structuralism. ${ }^{16}$ The book was received very positively. For example, the literary scholar, critic and translator Jozef Felix (1913-1977) praised the book for putting an end to the feuilleton style of writing about literature and to "pseudo-metric dilettante eclecticism, which was able to disguise itself with scholarly garb [...]."17

\section{The Scholarly and Political Dismissal of Formalism during the Slovak State}

After the Munich Agreement of 1938, Slovakia gained autonomy and became a client state of Nazi Germany that existed between March 1939 and April 1945. This political change brought about right-wing nationalist opposition to the recently discovered formalism.

Ján E. Bor (a pseudonym of Ernest Žatko, 1907-1991) was a catholic theologian and scholar of Romance literature. His book Metóda literárnej vedy ("The Method of Literary Studies", 1940) is a critique of the new developments in Slovak literary studies. Its main thrust was to expose one-sidedness in the methodology of literary analysis. ${ }^{18}$ The literary critic and historian Milan Pišút (1908-1984) wrote in his short article Formalizmus a štrukturalizmus published as early as 1934 that despite the unquestionable usefulness of the formal method one should not overrate it and should rather return to sociological and psychological criticism. ${ }^{19}$ Bor went even further in his critique of formalism, although his arguments were not as elaborate as they were abusive. He devoted one chapter to a critique of formalism from the right-wing nationalist viewpoint. In it, he tried to find answers to the following questions: Does formalism bring anything new? Why did it originate in Russia? Why was it accepted in the Czech lands and Slovakia?

Bor did not see anything really new in formalism. He considered the formalist discarding of the dichotomy between content and form as wordplay. ${ }^{20}$ As far as the origins of formalism in Russia are concerned, Bor wrote that Russian literary history was very conservative and behind the times in comparison with West European literary studies. The OPOJAZ had merely made a small revolution before the great political revolution and had radically broken away from the descriptive and ideological approach of the older generation of literary historians. In the Czech lands, formalism had taken a foot-

16 ŠTEVČEK, Ján: Mikulăšs Bakoš - zwischen Formalismus und Strukturalismus. In: Československý štrukturalizmus a viedenský scientizmus. Eds. Ján Bakoš - Peter Michalovič. Bratislava: Stimul, 1992, pp. 91-97.

17 FELIX, Jozef: Kniha o slovenskom verši. Elán. Orgán Spolku slovenských spisovatelov, Vol. 3, 1939, No. 10, p. 10.

18 BOR, Ján E.: Metóda literárnej vedy. Trnava: Fr. Urbánek a spol., 1940, p. 11.

19 PIŠÚT, Milan: Formalizmus a štrukturalizmus. Op. cit., p. 265.

20 BOR, Ján E.: Metóda literárnej vedy. Op. cit., p. 68. 
hold because it was a new revolutionary approach that suited the new generation of literary scholars. Roman Jakobson's relocation to Prague had also played a significant role. Moreover, Bor claimed, without any further elaboration, that the ground for the favourable reception of formalism in the Czech lands had been prepared by the famous literary critic F. X. Šalda (1867-1937).

But how is it possible that formalism was so well received in Slovakia? Bor argued that Slovakia had had a favourable attitude to Russia since time immemorial; Russia was often seen as a reservoir of spiritual life and energy in passive Slovakia. "As usual", Bor claimed, "formalism was accepted without the slightest critical examination. Every new thing is being accepted, and nobody can say about us that we are backward in everything." ${ }^{21}$ He blamed right-wing politicians for their passive and uncreative attitude because they neglected literature and art and offered a word of warning: "People think that everything is still alright and do not want to see where we are heading and how everything will later work to the disadvantage of those who have not been on guard." 22 The last two words of Bor's warning have a specific cultural significance. "Na stráž!" (On guard!) was the official salute of the nationalist Hlinka Guard, which was hostile to any opposition in the Slovak State. Bor did not deny that formalism "brought us something valuable in the given conditions" and that it contributed to the self-awareness of Slovak literary studies. ${ }^{23}$ However, he found the formalist approach dogmatic. ${ }^{24}$

Bakoš himself found Bor's critique inadequate. In his view, Bor did not understand the most basic principles of formalism. ${ }^{25}$ But Bor's attack was a far less serious threat to formalism and the nascent Slovak literary studies than the events after the release of Bakoš’s anthology Teória literatúry. The invectives against anti-fascist intellectuals, which included the young literary scholars, intensified with the accession of radical nationalists to power in 1940. State intervention took the form of police and censorial repressions. Some literary magazines, as well as the Association for Scientific Synthesis, were banned. The colportage of Bakošs anthology was forbidden in 1942 by the Central Office for State Security (Ústredňa štátnej bezpečnosti) under government decree no. 191 on the legal position of Jews dated 9 September $1941 .{ }^{26}$ The situation escalated after the book's publication with a poll in Národné noviny (The National Newspaper), in which it was placed together with other books of nadrealist authors and scholars associated with the Association for Scientific Synthesis at the top of the list of the most beautiful books of the year.

Gardista, the daily newspaper of the radical nationalists, reacted with outrage. It attacked the poll as a political provocation. ${ }^{27}$ Previously Gardista had published short

21 Ibidem, p. 64.

22 Ibidem, pp. 64-65.

23 Ibidem, p. 108.

24 Ibidem, p. 12 and 108.

25 BAKOŠ, Ján: Úvod. Op. cit., p. 10.

26 A copy of the document is reprinted in BAKOŠ, Ján: Avantgarda 38. Op. cit., p. 225.

27 Alibisti a aparátnici. Gardista, 18 December 1942, p. 1. 
reviews of the book. ${ }^{28}$ However, after the publication of a long review praising its contribution to Slovak literary studies, ${ }^{29}$ the newspaper published a disclaimer: "The review got into Gardista without the knowledge and contrary to the instructions of the editor-in-chief. However, it should be said about the book that it contains texts by communist and Jewish authors a fact which the author of the review, either out of ignorance or intentionally, concealed, trying to present the book in a sympathetic light to the Slovak reader." ${ }^{0}$

Bakoš could not refrain from replying. A month later, in the weekly Slovák, which was also associated with the Hlinka Gaurd, he managed to publish a reply. "Rumours are circulating in the Slovak public", Bakoš wrote, "which are based on a mistake and do not correspond to reality. ${ }^{" 11}$ He tried to defend formalism against the charges of communism. He explained that formalism was suppressed in Russia by official Marxist literary studies. He even quoted a statement from a meeting of the Slovak writer Mikulás Gacek with the secretary of the Union of Soviet Writers Mikhail Yakovlevich Apletin, who had said that such a book would have been deemed anti-Bolshevik and could not have been published in Russia. Bakoš argued that formalism was close to similar theoretical initiatives in European literary studies and was developed under the influence of German theory of art, literary studies and phonetics.

The heated debate reached its peak in the article titled Alibisti a aparátnici ("Alibists and apparatchiks") published in Gardista. It tried to identify the reasons for putting Bakoš's anthology on the list of the most beautiful books of the year. Bakoš was called a Bolshevik and formalism was linked with "a culture which impedes or disorients Slovak cultural development." The unsigned article blamed Bakoš for knowingly publishing a book by Jewish authors, i.e. knowingly breaking the law. It attacked him for not mentioning - when he published his response in Slovák - that the formalist authors were Jewish and that he was misguiding the public with claims that the book had been confiscated because the government and the police were against formalism. The article ends with a question highlighted in bold: "How long will publications and magazines that do not serve Slovak interests be subsidized with government funds?"

After this political dismissal of formalism, Ján E. Bor felt the need to react and, as he said, "to objectively deal" with the book. Apparently, he also wanted to retaliate for a personal insult (Bakoš's claim in the introduction to the book that Bor did not understand the principles of formalism). ${ }^{32}$ In an article published in Náš boj ("Our Fight"), Bor portrayed the formal method as one-sided with its emphasis on form and claimed its principles had been surpassed. For him, it is "unhealthy, dangerous, short-sighted" "mistaken, half-baked and condemnable" ${ }^{34}$ Moreover, according to Bor, scholarship should

Teória literatúry. Gardista, 11 July 1942, p. 7; Rastieme kultúrne. Gardista, 15 July 1942, p. 6.

Teória literatúry. Gardista, 27 September 1942, p. 18.

K referátu o knihe "Teória literatúry”. Gardista, 12 October 1942, p. 7.

BAKOŠ, Mikuláš: O autoroch knihy “Teória literatúry”. Slovák, 8 November 1942, p. 10.

BOR, Ján E.: Na okraj formálnej metody. Náš boj, Vol. 1, 1943, No. 8, pp. 198-203.

Ibidem, p. 199.

Ibidem, p. 203. 
not be pursued for its own sake. If it is, it is a luxury. It should serve a purpose: "In other countries, scholarship usefully participates in the higher development of spiritual and national life. Should we in Slovakia be an exception? [...] Slovak scholarship should show our existential right to the world [...] It should introduce extraordinary Slovak phenomena, racial and eminently Slovak issues, to the outside world [...]." ${ }^{55}$ In contrast, the formal method, as "a figment of communist heads not only negates the work for the whole but, in its broad application, it is also directly aimed against it [...]." ${ }^{36}$

\section{The Structuralist Initiatives after the Second World War and their Repudiation by the Stalinists}

The end of the Second World War brought another change of political regime in Slovakia. The country again became part of Czechoslovakia. Many scholars hoped that after a period of suppression of Jewish authors, Czechoslovak-oriented authors, and avant-garde writers, the coexistence of different aesthetic and ideological outlooks would be possible and Slovak culture would become pluralistic again.

The Association for Scientific Synthesis resumed its activities in October 1946. During this time of heated ideological and political debates, the members of the association joined the political left. They saw their place on the side of the most progressive initiatives, which were proposed by the communists. For them, Marxism was a suitable theory of social modernization. In the wake of the victory of the Soviet Union over fascism, the idea of Slavic unity also gained importance in Czechoslovakia. In general, the conditions for the acceptance of socialist ideas in society were very favourable. ${ }^{37}$ Even before the Second World War, Marxism was discussed at the meetings of the Association. However, this time its members actively sought to marry structuralism and dialectical materialism. ${ }^{38}$ Jan Mukařovský himself made an attempt to integrate structuralism into Marxism in his speech at the meeting of the Academic and Artistic Union of Matica slovenská in the city of Martin on 13 November $1948 .^{39}$

Oskár Čepan (1925-1992) identified three problem areas of literary studies in this period: 1. reckoning with the scholars who had collaborated with the Nazi regime; 2. revision of the former official idea of "Czechoslovakism", a political concept propagated during the first Czechoslovak Republic which had envisaged a unified Czechoslovak nation and had denied an independent existence to the Slovak nation; 3. the search for a new methodology of literary studies which would take into account its social function

35 Ibidem, p. 202.

36 Ibidem, p. 203. By "the whole", Bor means the nation.

37 BÍLIK, René: Duch na retazi. Sondy do literárneho života na Slovensku v rokoch 1945-1989. Bratislava: Kalligram, 2008, pp. 23-29.

38 BAKOŠ, Vladimír: Avantgardistický projekt modernity (Z dejín slovenskej vedeckej a umeleckej anvatgardy). Bratislava: Veda, 2006, pp. 33-39.

39 MUKAǨOVSKÝ, Jan: Kam speje dnešná teória umenia? Slovenské pohlady, Vol. 65, 1949, No. 4-5, pp. 263-276. 
in a national democracy. He points out that the third problem area did not result from any political agenda but from the conflict between the heirs of positivism and the adherents of structuralism. Positivism helped to correct the facts distorted by "the nationalist separatists" and "the Czechoslovakist centralists" of the previous decades. The minimalist positivist approach, which hardly allowed any scope for interpretation, became the target of criticism by the structuralists. ${ }^{40}$

However, Oskár Čepan and Anton Popovič ${ }^{41}$ claimed that the first phase of Slovak structuralism (1945-1948) had still been very close to formalism. Similarly, Stanislav Kostka (an alias of Stanislav Šmatlák), in his review of the state of Slovak literary studies after the war, - in which the main texts were Ján Brezina's monograph on the poetry of Ivan Krasko (Ivan Krasko, 1946), Vladimír Reisel's study of the poetry of Ladislav Novomeský (Poézia Laca Novomeského, 1946), and Viktor Kochol's study of a poem by the romantic poet Andrej Sládkovič (Dnešná problematika Mariny, 1946) - remarked that Brezina and Novomeský analysed only formal elements of the literary works they explored. He further warned that if the Slovak structuralists did not want to remain mere formalists, they would have to realize that even formal elements convey meaning. He praised Kochol for showing how formal elements contribute to meaning in Sládkovič's poem Marina. ${ }^{42}$

In 1948 Czechoslovakia became a communist state. Ideological interventions in literary studies were on the rise, totally suppressing the development of the discipline. Scholars faced a dilemma that was the consequence of ruthlessly applied politics of power. They could either accept the official ideology of Marxism-Leninism and participate in its propagation or give up their academic careers. Some chose one of these options willingly, others unwillingly. The members of the Association for Scientific Synthesis did not see any contradiction in their participation in the social reformation that was taking place. Their expectations were, however, not met. Their activities fell out of favour with those in power because they were not sufficiently aligned with the official ideology. In addition, they were commonly associated with the part of Slovak intelligentsia which, at the time of intensifying class struggle, was supposed to be despised or, in the worst case, physically eliminated. As a consequence, the association was forced to dissolve in February $1950 . .^{43}$

After the Second World War, the protagonists of the "formalism debate" that had taken place in the early 1940s went their separate ways. Ján E. Bor emigrated to Argentina. Mikuláš Bakoš stayed in Slovakia, developing Slovak literary studies. However, he did not remain immune to the monstrosity of the communist ideology as the titles of his books written in the 1950s show: O socialistickom realizme ("On Socialist Realism", 1952), Stalin a umenie ("Stalin and Art", 1953), and Literatúra a nadstavba ("Literature

40 ČEPAN, Oskár: Slovenská literárna veda v rokoch 1945-1966. Slovenská literatúra, Vol. 14, 1967, No. 1, pp. 81-83.

41 POPOVIČ, Anton: Vývinové tendencie slovenskej literárnej vedy. Slovenské pohlady, Vol. 81, 1965, No. 5, p. 68.

42 KOSTKA, Stanislav: Štrukturalizmus v slovenskej literárnej vede. Verbum, Vol. 2, 1947, pp. 240-245.

43 BAKOŠ, Ján : Avantgardistický projekt modernity. Op. cit., p. 40. 
and Superstructure”, 1960). In 1951, Bakoš was arrested and spent most of the year in pre-trial detention. He came out a broken man. ${ }^{44}$

The revival of structuralism immediately after the Second World War was thus very short-lived. In the 1950s, structuralism disappeared into "discrete anonymity" 45 . The word "formalism" gained a pejorative meaning. "Formalist" was a designation applied to "everything that swerved from the wooden canon of socialist realist art, which adhered to and imitated (- as in our country -) the art and the non-art of the last century. In short, formalism became a dangerous anti-Marxist inimical deviation from which everybody sought to distance themselves [...]". ${ }^{46}$

Following the Congress of Writers-Communists (Aktív spisovatelov-komunistov) held on 30 March 1951 and later on 6 and 7 May 1951 in Bratislava, Mikuláš Bakoš was forced to make a public move of self-criticism in the weekly Nové slovo ("The New Word"). ${ }^{47} \mathrm{He}$ did so before Jan Mukařovský, who published his self-critical piece several months later. ${ }^{48}$ "Structuralist theories applied in literature were a manifestation of cosmopolitanism and moved the development of literary studies in the anti-national direction that found its primary expression in the poetry of nadrealists," Bakoš wrote at the beginning of his article. He admitted that he had falsely seen this method as the most advanced theoretical system developed in Czechoslovak literary studies and had greatly contributed to its acceptance. He was able to understand "the shortcomings of structuralism, its unscientific character, with the help of the scientific world view of Marxism-Leninism, the Soviet science, and the ideological education work of our native party, the Communist Party of Czechoslovakia." He repudiated formalism and structuralism as unscientific and decadent bourgeois theory. Now he argued that it had separated content from form because, following Kant, it had given prominence to form over content. In this way, the formalists and the structuralists had detached art from life in their analysis and had adopted a non-dialectical, metaphysical position. All attempts to reconcile formalism and structuralism with dialectical materialism were false and mistaken. They deprived literature of its essence as social ideology. In Bakoš's new view, literature should be a tool of social progress. Structuralism, as well as bourgeois art, were just a tool of "the imperialist bourgeoisie to suppress the struggle of the working class for freedom"; they were "anti-national, anti-humanistic, and cosmopolitan." He admitted that his own books, Teória literatúry. Výbor z „formálnej metódy“("Theory of Literature. A Selection from the "Formal Method", 1941) and Vývin slovenského verša ("Development of Slovak Verse", 1939) had gained undue respect. In reality, they only had reduced poetry to a verse technique. He also rejected his previous attempts to reconcile structuralism

44 BAKOŠOVÁ-HLAVENKOVÁ, Zuzana: Magnetické polia literatúry a ich osamelý bežec M. B. In: Mikuláš Bakoš a moderná literárna veda. Ed. Dušan Teplan. Nitra: Univerzita Konštantína Filozofa v Nitre, 2016 , p. 13.

45 MATEJOV, Fedor - ZAJAC, Peter: Štrukturalizmus v slovenskej literárnej vede. In: Od iniciatívy k tradícii. Štrukturalizmus v slovenskej literárnej vede od 30. rokov po súčasnost́. Eds. Fedor Matejov - Peter Zajac. Brno: Host, 2005, p. 12.

46 NOVOMESKÝ, Ladislav: S avantgardou a v avantgarde (Poznámky pri sedemdesiatinách Romana Jakobsona). Slovenská literatúra, Vol. 14, 1967, No. 1, p. 6.

47 BAKOŠ, Mikuláš : Proti kozmopolitizmu v literárnej vede. Nové slovo, 10 May 1951, pp. 383-384.

48 MUKǍ̌OVSKÝ, Jan: Ke kritice štrukturalizmu v naši společnosti. Tvorba, Vol. 20, 1951, No. 40, pp. 964-966. 
with Marxism and declared them incompatible. Bakoš confessed that he had misguided his younger colleagues and poets.

\section{The Revival of the Interest in Structuralism in the 1960s}

Structuralism emerged out of anonymity in the 1960s with progressing de-Stalinization, which had a late start in Czechoslovakia. In the mid-1960s, the former members of the Association for Scientific Synthesis again tried to revive the organization, but their efforts were unsuccessful. ${ }^{49}$

However, scholarly discussion of structuralism was rekindled. In 1962, Ján Rozner (1922-2006) made an attempt to reconcile structuralism with Marxism. He claimed that one could approach the problem of structuralism in two ways: polemically, i.e., by attacking it, or historically. ${ }^{50}$ Although he dismissed structuralism as a literary theory that could have any significance for contemporary literary studies, he tried to rehabilitate it. He said that structuralism was "a detour on the way to Marxism" ${ }^{51}$ Or more precisely: "Structuralism is an attempt to bring the formal method closer to Marxism [...] but also a revision of the formal method from the point of view of neo-positivism." ${ }^{2}$ In a communist future, where class differences would be completely eliminated, he argued, art would be absolutely free from social functions; there would be room for pure art. Communism would thus make it possible for art to become what it could not be in antagonistic social formations. This was the structuralists' hypothesis, according to Rozner.

In 1964, Mikuláš Bakoš published a collection of his studies written in the previous 30 years entitled Problémy literárnej vedy včera a dnes ("Problems of Literary Studies Yesterday and Today"). In the afterword, he rejected the nihilist negation of structuralism and argued for developing what had been proven to be of use to literary studies in the present. $^{53}$

In the mid-1960s, the book O tvar a strukturu v slovesném uméni ("On the Form and Structure of Verbal Art", 1966) had a significant resonance across the whole country. It reacted to the revived interest in formalism and structuralism in Czechoslovakia and abroad and tried to deconstruct it philosophically. The author was the Czech Marxist literary scholar and communist politician Ladislav Štoll (1902-1981), who was a member of the Central Committee of the Communist Party of Czechoslovakia. The Slovak literary scholar Milan Hamada (b. 1933) wrote a polemical article on Štoll's book. Hamada argued that the power of Marxism did not lie in intolerance and exclusiveness but in its ability to integrate other theories. According to him, one should not try to destroy the philosophical tendencies that had given rise to formalism and structuralism. Instead, it

49 BAKOŠ, Ján: Avantgardistický projekt modernity. Op. cit., p. 42.

50 ROZNER, Ján: O štrukturalizme polemicky a historicky. Slovenská literatúra, Vol. 10, 1962, No. 1, pp. 64-73.

51 Ibidem, p. 64.

52 Ibidem, p. 75.

53 BAKOŠ, Mikuláš: Problémy literárnej vedy včera a dnes. Bratislava: Vydavatel'stvo Slovenskej akadémie vied, 1964, p. 363. 
was better to transcend them and give them meaning. Structuralism and Marxism were not in conflict; they were complementary. ${ }^{54}$ All these public statements (even if Rozner's was somewhat confused) represent a significant change in the assessment of formalism and structuralism in Slovakia at that time.

Similarly, František Miko (1920-2010), an important Slovak linguist and literary scholar, saw a confirmation of the principle of dialectical development (thesis - antithesis - synthesis) in the reception of structuralism. First, Miko argued in 1969, it had polemicized against positivism, then it had been negated by Marxism, and finally, they had become one. The synthesis, according to Miko, was achieved in Mikuláš Bakoš’s study entitled Literárna história a historická poetika ("Literary History and Historical Poetics"), which first appeared as a cyclostyle paper at the Institute of Literary Studies of the Slovak Academy of Sciences and was published in book form in 1972. ${ }^{55}$

In the wake of the rehabilitation of structuralism, the formalist works of Mikulás Bakoš were republished in the period between 1966 and $1971 .^{56}$ The Slovak structuralists again felt the need to explore the foundations of their theory. In 1971, translations of Vladimir Propp's Morphology of the Folktale, Viktor Shklovsky's Theory of Prose and Boris Tomashevsky's Theory of Literature (Poetics) appeared. In the afterword to Tomashevsky's book, Dušan Slobodník (1927-1992) wrote that the book was neither the last word in the development of Boris Tomashevsky's views nor in literary scholarship. He described it as "an important milestone in the development of literary studies". ${ }^{57}$

In the late 1960s, some theorists felt the need to comment on formalism in order to substantiate their own theoretical approaches. For example, Anton Popovič explored the history of Slovak literary studies in relation to formalism in several publications. ${ }^{58}$ Slovak Marxist-structuralist comparative literary theory as it was developed by Mikuláš Bakoš’s pupil Dionýz Ďurišin (1929-1997) is also an heir to formalism. Ďurišin, who became a leading theorist of comparative literature, devoted one chapter of his 1970 monograph $Z$ dejín a teórie literárnej komparatistiky ("On the History and Theory of Comparative Literature") to formalism. According to Durišin, the formal method "managed to defend the basic theoretical foundations of the comparative interliterary approach to literary phenomenon [...]." ${ }^{59}$ However, he argues further that the formalists did not reach the multilateral research of interliterary relations and connections. This resulted in a limited object and purpose of comparative research that was too confined to the study of the development

54 HAMADA, Milan: Spor so štrukturalizmom. Slovenské pohlady, Vol. 83, 1967, No. 6, pp. 61-63.

55 MIKO, František: Štrukturalizmus a vývinový aspekt literatúry. Slavica Slovaca, Vol. 4, 1969, No. 4, 1969, pp. 375-379.

56 Teória literatúry was republished in 1971; the $3^{\text {rd }}$ edition of Vývin slovenského verša appeared in 1966, the $4^{\text {th }}$ in 1968 under the title Vývin slovenského verša od školy Štúrovej ("Development of Slovak Verse since the Štúr school”).

57 SLOBODNÍK, Dušan: Poznámka o autorovi. In: TOMAŠEVSKIJ, Boris: Poetika. Teória literatúry. Trans. Dušan Slobodník - Soňa Lesňáková. Bratislava: Smena, 1971, p. 302.

58 See Popovič's s Formálna metóda v slovenskej literárnej vede and Štrukturalizmus v slovenskej vede 1931-1949.

59 ĎURIŠIN, Dionýz: Z dejin a teórie literárnej komparatistiky. Bratislava: Vydavatel’stvo Slovenskej akadémie vied, 1970, p. 66. 
of national literature. It did not culminate in the study of the development of world literature which was the purpose of comparative studies in Durišin's view. Formalism was not able to progress to this stage, although it had the potential to do so. According to Durišin, comparative literature started developing with formalism, but later its influence on the discipline was hampered. He, therefore, saw formalism as "a legacy which contains a lot of constructive stimuli and elements even for contemporary comparative theory and literary-historical practice". ${ }^{60}$

During the Prague Spring of 1968, Roman Jakobson returned for a visit to Czechoslovakia. For fear of an international scandal, the state authorities allowed him to participate at the $\mathrm{VI}^{\text {th }}$ International Congress of Slavists in Prague as an invited guest. As a member of the delegation of the International Committee of Slavists, he was received by President Ludvík Svoboda and was awarded the Doctor Honoris Causa title by Charles University in Prague and J. E. Purkyně University in Brno (now Masaryk University). It is a less known fact that Jakobson also received a memorial medal from the Slovak Academy of Sciences in Bratislava, and his Czechoslovak trip was originally planned to finish in the Slovak city of Nitra at the Cabinet for Literary Communication and Experimental Methodics, newly founded by Anton Popovič and František Miko. However, when the Warsaw Pact armies invaded Czechoslovakia on 21 August 1968, Jakobson had to flee from his uniformed countrymen to Vienna. ${ }^{61}$

\section{Slovak Literary Studies in the Normalization Period}

The liberalization of Czechoslovak society in the 1960s, which led to the Prague Spring, had a terrible aftermath. The new Soviet-backed government restored the political and economic values that had prevailed before and introduced a process they called "normalization". An important document offering the official interpretation of the events of the Prague Spring and the Warsaw pact armies' invasion was Poučeni z krizového vývoje ve straně a společnosti po XIII. sjezdu KSČ ("Lessons from the Crisis in the Party and the Society after the XIII ${ }^{\text {th }}$ Congress of the Communist Party of Czechoslovakia"), issued by the Central Committee of the Communist Party of Czechoslovakia on 10 December 1970. The "Lessons" portrayed events and the atmosphere of the 1960s as a "crisis in society" and a "counter-revolution."

The document became the guideline for the next two decades. Literature and literary studies again came under political pressure. The situation was similar to that after 1948, although the conditions were less oppressive, especially in the Slovak part of the

60 Ibidem, p. 68.

61 HERMANN, Tomáš - ZELENKA, Miloš: Válečný spis Romana Jakobsona. Mezi strukturální lingvistikou, slavistikou a politizujicí ideologií. In: JAKOBSON, Roman: Moudrost starých Čechi̊. Komentovaná edice s navazujíci exilovou polemikou. Praha - Červený Kostelec: Ústav pro soudobé dějiny AV C̆R - Pavel Mervart, 2015, p. 99. A year before, an issue of Slovenská literatúra, Vol. 14, 1967, No. 1 was dedicated to Jakobson. It contained Jakobson's study, Gramatická štruktúra veršov Janka Krála, which analyzed the grammatical structure of the poetry of the Slovak romantic poet Janko Král. 
country. Some of the previously mentioned literary scholars, and others, were forced into internal exile. Following the political checks at the Institute of Slovak Literature of the Slovak Academy of Sciences in 1972, Milan Hamada had to leave the institute and was not allowed to publish because of his civil and political attitudes. Ján Rozner met the same fate. In 1977 he finally emigrated to Germany. Book projects were cancelled, including an anthology of Jakobson's studies, which was due to be published in $1971 .^{62}$

Slovak literary scholars commemorated the $15^{\text {th }}$ anniversary of the "Lessons" with the publication entitled Dejinné poučenie a literatúra ("Historical Lessons and Literature", 1986). The publication was "an expression of atonement" for the fiasco with the most important literary-historical project of the 1970s, Slownik slovenských spisovatelov ("Dictionary of Slovak Writers"), which was pulped for including authors uncomfortable to the communist regime. ${ }^{63}$ Several contributions attacked the "right-wing opportunism" and "revisionism" of the 1960s. Valér Petko, for example, says that the 1960s brought "a confrontation of two literary conceptions. One of them, no matter how the right-wing opportunists tried to simplify or vulgarize it, respected the perspective of historicism, social determination, party-spirit, and in essence corresponded with the Marxist understanding of art and literature, whereas the other one unambiguously headed for aesthetic formalism and irrationality. However, regarding these two conceptions (and the right-wing opportunists bamboozled for some time), it was not only about an encounter of certain forms and techniques (which can complement each other) but about a confrontation of two world views and ideologies, projected into the world of art and literature." 64

Despite the "Lessons", Slovak literary studies of the 1970s and the 1980s drew partly on the formalist and structuralist legacy. Several scholars were inspired by structuralism (Anton Popovič, Dionýz Ďurišin, František Miko, Oskár Čepan, Milan Šútovec, Jozef Hvišč, Peter Zajac, Peter Liba, Tibor Žilka, Lubomír Plesník and others) even if they now also made use of other methodological principles.

\section{Conclusion}

The development of Slovak literary studies in the $20^{\text {th }}$ century was full of dramatic changes. The social and political transformations clearly made an impact on all areas of literary scholarship. The changes affected not only the external or administrative aspects of literary scholarship but also raised methodological problems. Formalism came to Slovakia quite early in the mid-1930s, at a time when Slovak literary scholars were trying to develop the discipline with the help of Czech scholars. The interest of Slovak scholars in formalism was connected with their efforts to explore the foundations of structuralism

62 It appeared only in 1991. See JAKOBSON, Roman: Lingvistická poetika. Bratislava: Tatran, 1991.

63 ŽITNÝ, Milan: Čo nebolo vo Winczerovej bilancii. World Literature Studies, Vol. 7, 2015, No. 2, p. 92.

64 PEŤKO, Valér: K pravicovým tendenciám v literatúre a literárnej kritike šestdesiatych rokov. In: Dejinné poučenie a literatúra. Ed. Karol Rosenbaum. Bratislava: Nakladatelstvo Pravda, 1986, p. 45. There were also other publications of this kind. See, for example, HRZALOVÁ, Hana - ROSENBAUM, Karol (eds.): Kritika buržoáznych koncepcii v literárnej vede (Litteraria XXIII). Bratislava: Veda, vydavatelstvo SAV, 1982. 
and to contribute something of their own, independently of the Czechs, to the development of the new structuralist theory. Also, in contrast to Czech structuralism, Slovak structuralism found inspiration in the scientism of the Vienna Circle. Unfortunately, the political situation in the country in the 1940 s and the 1950 s was not favourable to the formalist/structuralist approach to literature. The development of Slovak literary studies was hampered by oppressive ideological interventions. However, in the 1960 s, Slovak structuralism started flourishing again, and interest in formalism was briefly revived until it was once more suppressed by the political establishment. After the Velvet Revolution of 1989, structuralism was rehabilitated for the third time. Nevertheless, at that time, the structuralist initiative had already lost the momentum to stimulate the development of literary theory. ${ }^{65}$

\section{Literature}

Alibisti a aparátnici. Gardista, 18 December 1942, p. 1.

BAKOŠ, Ján: Štrukturalizmus na Slovensku ako symbolický skok. In: Československý štrukturalizmus a viedenský scientizmus. Ed. Ján Bakoš - Peter Michalovič. Bratislava: Stimul, 1992, pp. 8-18.

BAKOŠ, Mikuláš: Teória literatúry. Výbor z „formálnej metódy“. Trnava: Fr. Urbánek a spol., 1941.

BAKOŠ, Mikuláš: O autoroch knihy “Teória literatúry”. Slovák, 8 November 1942, p. 10.

BAKOŠ, Mikuláš: Proti kozmopolitizmu v literárnej vede. Nové slovo, 10 May 1951, pp. 383-384.

BAKOŠ, Mikuláš: O socialistickom realizme. Bratislava: Štátne nakladatel'stvo v Bratislave, 1952.

BAKOŠ, Mikuláš: Stalin a umenie. Bratislava: Slovenský spisovatel', 1953.

BAKOŠ, Mikuláš: Literatúra a nadstavba. Bratislava: Slovenský spisovatel', 1960.

BAKOŠ, Mikuláš: Problémy literárnej vedy včera a dnes. Bratislava: Vydavatel'stvo Slovenskej akadémie vied, 1964.

BAKOŠ, Mikuláš: Vývin slovenského verša od školy Štúrovej. $3^{\text {rd }}$ Edition. Bratislava: Vydavatelstvo Slovenskej akadémie vied, 1966.

BAKOŠ, Mikuláš: Áno a nie. In: Avantgarda 38. Ed. Mikuláš Bakoš. Bratislava: Slovenský spisovatel, 1969, pp. 181-182.

BAKOŠ, Vladimír: Avantgardistický projekt modernity (Z dejín slovenskej vedeckej a umeleckej avantgardy). Bratislava: Veda, 2006.

BAKOŠOVÁ-HLAVENKOVÁ, Zuzana: Magnetické polia literatúry a ich osamelý bežec M. B. In: Mikuláš Bakoš a moderná literárna veda. Ed. Dušan Teplan. Nitra: Univerzita Konštantína Filozofa v Nitre, 2016, pp. 9-25.

BÍLIK, René: Duch na retazi. Sondy do literárneho života na Slovensku v rokoch 1945-1989. Bratislava: Kalligram, 2008.

BOR, Ján E.: Metóda literárnej vedy. Trnava: Fr. Urbánek a spol., 1940.

BOR, Ján E.: Na okraj formálnej metódy. Náš boj, Vol. 1, 1943, No. 8, pp. 198-203.

ČEPAN, Oskár: Slovenská literárna veda v rokoch 1945-1966. Slovenská literatúra, Vol. 14, 1967, No. 1, pp. 79-97.

65 See MATEJOV, Fedor - ZAJAC, Peter: Štrukturalizmus v slovenskej literárnej vede. Op. cit., p. 19. 
ĎURIŠIN, Dionýz: Z dejín a teórie literárnej komparatistiky. Bratislava: Vydavatel'stvo Slovenskej akadémie vied, 1970.

FELIX, Jozef: Kniha o slovenskom verši. Elán. Orgán Spolku slovenských spisovatelov, Vol. 3, 1939, No. 10, pp. 9-10.

HAMADA, Milan: Spor so štrukturalizmom. Slovenské pohlady, Vol. 83, 1967, No. 6, pp. 61-63.

HERMANN, Tomáš - ZELENKA, Miloš: Válečný spis Romana Jakobsona. Mezi strukturálni lingvistikou, slavistikou a politizujicí ideologií. In: JAKOBSON, Roman: Moudrost starých Čechů. Komentovaná edice s navazující exilovou polemikou. Praha - Červený Kostelec: Ústav pro soudobé dějiny AV ČR - Pavel Mervart, 2015, pp. 17-106.

HRZALOVÁ, Hana - ROSENBAUM, Karol (eds.): Kritika buržoáznych koncepcii v literárnej vede (Litteraria XXIII). Bratislava: Veda, vydavatel'stvo SAV, 1982.

JAKOBSON, Roman: Gramatická štruktúra veršov Janka Krála. Slovenská literatúra, Vol. 14, 1967, No. 1, pp. 67-78.

JAKOBSON, Roman: Lingvistická poetika. Bratislava: Tatran, 1991.

K referátu o knihe "Teória literatúry". Gardista, 2 October 1942, p. 7.

KOSTKA, Stanislav: Štrukturalizmus v slovenskej literárnej vede. Verbum, Vol. 2, 1947, pp. 240-245.

MATEJOV, Fedor - ZAJAC, Peter (eds.): Štrukturalizmus v slovenskej literárnej vede. In: Od iniciatívy k tradícii. Štrukturalizmus v slovenskej literárnej vede od 30. rokov po súčasnoste. Eds. Fedor Matejov - Peter Zajac. Brno: Host, 2005, pp. 7-22.

MIKO, František: Štrukturalizmus a vývinový aspekt literatúry. Slavica Slovaca, Vol. 4, 1969, No. 4, pp. 375-379.

MUKAŘOVSKÝ, Jan: Kam speje dnešná teória umenia? Slovenské pohlady, Vol. 65, 1949, no. 4-5, pp. 263-276.

MUKAŘOVSKÝ, Jan: Ke kritice štrukturalismu v naši společnosti. Tvorba, Vol. 20, 1951, No. 40, pp. 964-966.

NOVOMESKÝ, Ladislav: S avantgardou a v avantgarde (Poznámky pri sedemdesiatinách Romana Jakobsona). Slovenská literatúra, Vol. 14, 1967, No. 1, pp. 3-10.

PAŠTEKOVÁ, Soňa: Niekolko poznámok k Bakošovým prekladom prác ruských formalistov (B. Ejchenbaum: Ako je napisaný Gogolov Plášt? ). In: Preklad a tlmočenie XII. Hybridita a kreolizácia v preklade a translatológii. Eds. Anita Hutková - Martin Dvojčoš. Banská Bystrica: Belanium, 2016, pp. 85-94.

PAŠTEKOVÁ, Soňa: Koncepcie ruského formalizmu a Mikulāš Bakoš (literárnovedná reflexia v peripetiách doby). In: Dialog kultur IX. Sborník příspěvků z mezinárodní vědecké konference Hradec Králové 17.-18. ledna 2017. Ed. Jaroslav Sommer. Hradec Králové: Gaudeamus, 2018, pp. 25-39.

PIŠÚT, Milan: Formalizmus a štrukturalizmus. Slovenské smery umelecké a kritické, Vol. 1, 19331934, No. 1, pp, 262-268.

POPOVIČ, Anton: Vývinové tendencie slovenskej literárnej vedy. Slovenské pohlady, Vol. 81, 1965, No. 5, pp. 67-73.

POPOVIČ, Anton: Formálna metóda v slovenskej literárnej vede. Slovenské pohlady, Vol. 81, 1965, No. 12, pp. 81-90.

POPOVIČ, Anton: Štrukturalizmus v slovenskej vede 1931-1949. Martin: Matica slovenská, 1970.

PEŤKO, Valér.: K pravicovým tendenciám v literatúre a literárnej kritike šesṫdesiatych rokov. In: Dejinné poučenie a literatúra. Ed. Karol Rosenbaum. Bratislava: Nakladatelstvo Pravda, 1986, pp. 34-48. 
PROPP, Vladimir J.: Morfológia rozprávky. Trans. Nadežda Čepanová. Bratislava: Tatran, 1971.

Rastieme kultúrne. Gardista, 15 July 1942, p. 6.

ROZNER, Ján: O štrukturalizme polemicky a historicky. Slovenská literatúra, Vol. 10, 1962, No. 1, pp. 64-73.

SLOBODNÍK, Dušan: Poznámka o autorovi. In: TOMAŠEVSKIJ, Boris: Poetika. Teória literatúry. Trans. Dušan Slobodník - Soňa Lesňáková. Bratislava: Smena, 1971, pp. 299-302.

ŠKLOVSKIJ, Viktor: Teória prózy. Trans. Nadežda Čepanová. Bratislava: Tatran, 1971.

ŠTEVČEK, Ján: Mikuláš Bakoš - zwischen Formalismus und Strukturalismus. In: Československý štrukturalizmus a viedenský scientizmus. Eds. Ján Bakoš - Peter Michalovič. Bratislava: Stimul, 1992, pp. 91-97.

ŠTOLL, Ladislav: O tvar a strukturu v slovesném uměni. Praha: Československý spisovatel, 1966.

Teória literatúry. Gardista, 11 July, 1942, p. 7.

Teória literatúry. Gardista, 27 September 1942, p. 18.

TEPLAN, Dušan (ed.): Mikuláš Bakoš a moderná literárna veda. Nitra: Univerzita Konštantína Filozofa v Nitre, 2016.

TOMČÍK, Miloš: Bratislauské roky Jana Mukařouského. Slovenská literatúra, Vol. 38, 1991, No. 5-6, pp. 346-357.

ŽITNÝ, Milan: Čo nebolo vo Winczerovej bilancii. World Literature Studies, Vol. 7, 2015, No. 2, pp. 88-96.

doc. Mgr. Róbert Gáfrik, PhD.

Institute of World Literature, Slovak Academy of Sciences

Dúbravská cesta 9, 84104 Bratislava, Slovakia

robert.gafrik@savba.sk 